\title{
Is Renal $\beta$-Adrenergic-WNK4-NCC Pathway Important in Salt Hypertension of Dahl Rats?
}

\author{
J. ZICHA ${ }^{1}$, S. HOJNÁ ${ }^{1}$, Z. VAŇOURKOVÁ ${ }^{2}$, L. KOPKAN ${ }^{2}$, I. VANĚČKOVÁ ${ }^{1}$ \\ ${ }^{1}$ Institute of Physiology, Czech Academy of Sciences, Prague, Czech Republic, ${ }^{2}$ Institute of Clinical \\ and Experimental Medicine, Prague, Czech Republic
}

Received September 2, 2019

Accepted October 1, 2019

Epub Ahead of Print October 25, 2019

\section{Summary}

In 2011 Fujita and coworkers proposed that $\beta$-adrenergic stimulation causes decreased serine/threonine-protein kinase WNK4 transcription leading to the activation of $\mathrm{Na}-\mathrm{Cl}$ cotransporter (NCC) which participates in salt sensitivity and salt hypertension development in rodents. The aim of our study was to investigate whether the above hypothesis is also valid for salt hypertension of Dahl rats, which are characterized by high sympathetic tone and abnormal renal sodium handling. Male 8-week-old salt-sensitive (SS/Jr) and salt-resistant (SR/Jr) Dahl rats were fed either low-salt diet (LS, $0.4 \% \mathrm{NaCl}$ ) or high-salt diet (HS, $4 \% \mathrm{NaCl}$ ) for 6 weeks. Half of the animals on either diet were chronically treated with non-selective $\beta$-blocker propranolol $(100 \mathrm{mg} / \mathrm{kg} / \mathrm{day})$. At the end of the experiment diuresis and sodium excretion were measured prior and after hydrochlorothiazide injection (HCTZ, $10 \mathrm{mg} / \mathrm{kg} \quad$ i.p.). Furthermore, blood pressure (BP), heart rate (HR), sympathetic (pentolinium $5 \mathrm{mg} / \mathrm{kg}$ i.v.) and NO-dependent (L-NAME $30 \mathrm{mg} / \mathrm{kg}$ i.v.) BP components were determined. Chronic HS diet feeding increased BP through sympathoexcitation in SS/Jr but not in $\mathrm{SR} / \mathrm{Jr}$ rats. Concomitant propranolol treatment did not lower BP in either experimental group. Under the conditions of low salt intake HCTZ increased diuresis, natriuresis and fractional sodium excretion in SR/Jr but not in SS/Jr rats. HS diet feeding attenuated renal response to $\mathrm{HCT}$ in $\mathrm{SR} / \mathrm{Jr}$ rats, whereas no HCTZ effect was observed in SS/Jr rats fed HS diet. Propranolol treatment did not modify diuresis or natriuresis in any experimental group. In conclusions, our present data do not support the idea on the essential importance of renal $\beta$-adrenergic-WNK4-NCC pathway in pathogenesis and/or maintenance of salt hypertension in Dahl rats.

\section{Key words}

Sympathetic nervous system - $\beta$-adrenergic blockade - Renal sodium excretion - NCC cotransporter - Hydrochlorothiazide • Serine/threonine-protein kinase WNK4

\section{Corresponding author}

J. Zicha, Institute of Physiology, Czech Academy of Sciences, Videnska 1083, 14220 Prague 4, Czech Republic. E-mail: zicha@biomed.cas.cz

\section{Introduction}

High salt intake is considered to be one of the major factors in the pathogenesis and maintenance of human hypertension. Salt sensitive subjects are characterized by enhanced increase of blood pressure (BP) occurring during the exposure to salt loading (Fujita et al. 1980). The mechanism of increased salt sensitivity is still unclear, but there is an attractive hypothesis on the participation of renal $\beta$-adrenergic-WNK4 pathway in salt sensitivity and salt hypertension in rodents $(\mathrm{Mu}$ et al. 2011). It was suggested that $\beta_{2}$-adrenergic stimulation causes decreased transcription of the gene encoding WNK4, which is a regulator of sodium reabsorption. This pathway involves cAMP-dependent inhibition of histone deacetylase- 8 and increased histone acetylation, leading to binding of the glucocorticoid receptor to a negative glucocorticoid-responsive element in the promoter region. Mu et al. (2011) suggested that in rat models of salt hypertension with sympathetic hyperactivity, salt loading suppressed the renal WNK4 expression and 
activated thiazide-sensitive sodium-chloride cotransporter (NCC), leading to sodium retention and the induction of salt-sensitive forms of hypertension.

Salt hypertension in salt-sensitive Dahl rats (Dahl et al.1962) has been a subject of our research for more than 30 years (for review see Zicha et al. 2012). This was a reason why we decided to test the above hypothesis proposed by Fujita (2014) in this hypertensive model. Salt hypertensive Dahl rats are characterized by sympathoexcitation of central origin (Mark 1991, Huang and Leenen 1998, Zicha et al. 2001, Dobešová et al. 2002) as well as by numerous renal abnormalities (Alvarez-Guerra et al. 2002, Aoi et al. 2004, Amin et al. 2011, Nishimoto and Fujita 2015, Vokurková et al. 2015, Pavlov and Starushenko 2017, Kittikulsuth et al. 2018). Thus, we could expect increased $\beta$-adrenergic suppression of renal WNK4 pathway which could be prevented by chronic $\beta$-adrenergic blockade with non-selective $\beta$-blocker propranolol. It was demonstrated in late 1970s that chronic administration of thiazide diuretics in high-salt diet can almost prevent hypertension development in salt-sensitive Dahl rats (Iwai et al. 1977, Tobian et al. 1979). This finding has been confirmed by several other labs (Sharma et al. 1984, Yamada et al. 2011, Wei et al. 2017). Chronic treatment of salt-sensitive animals with hydrochlorothiazide (HCTZ) also attenuates saltinduced renal damage consisting of podocyte injury, peritubular capillary loss, tubular atrophy, macrophage infiltration and interstitial fibrosis (Wei et al. 2017). The activation of NCC through $\beta$-adrenergic-WNK4 pathway could cause the augmented natriuretic response to HCTZ in salt hypertensive animals. However, the information on the acute natriuretic response to HCTZ in Dahl rats is still missing.

The aim of our study in salt-sensitive and saltresistant Dahl rats was to evaluate BP effects of chronic $\beta$-adrenergic blockade by propranolol and the impact of this pharmacological intervention on natriuretic response to acute hydrochlorothiazide administration. The obtained results might help us to evaluate the importance of renal $\beta$-adrenergic-WNK4 pathway in salt sensitivity and salt hypertension of Dahl rats.

\section{Material and Methods}

Inbred salt-sensitive $(\mathrm{SS} / \mathrm{Jr})$ and salt-resistant $(\mathrm{SR} / \mathrm{Jr})$ Dahl rats aged 8 weeks (young adult rats) were used in the experiments. The animals were obtained from the breeding colony of the Institute of Physiology CAS in Prague and housed under the controlled conditions $\left(23 \pm 1{ }^{\circ} \mathrm{C}, 12 \mathrm{~h} \mathrm{~L} / \mathrm{D}\right.$ cycle) with tap water to drink and fed a low-salt (LS, $0.4 \% \mathrm{NaCl})$ or high-salt (HS, $4 \% \mathrm{NaCl}$ ) diets during the experiment lasting 6 weeks. In each experimental group $50 \%$ animals were treated with nonselective $\beta$-blocker propranolol $(100 \mathrm{mg} / \mathrm{kg} /$ day $)$ in the drinking fluid throughout the whole experiment.

All the procedures and experimental protocols were performed in accordance with guidelines and practice established by the Ethical Committees of the Institute of Physiology CAS, and conformed to the European Convention on Animal Protection and Guidelines on Research Animal Use.

Natriuretic response to acute hydrochlorothiazide administration

Before the end of the experiment the rats were placed individually in metabolic cages and urine was collected prior and after hydrochlorothiazide administration $(10 \mathrm{mg} / \mathrm{kg}$, i.p.). In the first series of experiments, which started at 8 a.m., the urine was collected for $4 \mathrm{~h}$ before and $4 \mathrm{~h}$ after HCTZ injection in all experimental groups. Further experiments were carried out in animals of both genotypes fed either LS or HS diet that were not treated with propranolol. In this series, which began at 4 p.m., the urine was collected for $16 \mathrm{~h}$ overnight without HCTZ application. Two days later HCTZ was injected just before the repeated urine collection. Separate groups of rats (not treated with propranolol) received furosemide injection $(10 \mathrm{mg} / \mathrm{kg}$ i.p.) and urine was collected overnight. All experiments were repeated twice. Urinary volume as well as urinary and plasma concentrations of sodium and creatinine were determined. Sodium excretion as well as fractional sodium excretion were calculated.

Participation of major vasoactive systems in BP maintenance (vasoactive balance)

One week later, the changes of mean arterial pressure (MAP) elicited by the sequential blockade of major vasoconstrictor and vasodilator systems (reninangiotensin system, sympathetic nervous system and NO) were determined in conscious cannulated rats. One day prior to the experiment two polyethylene cannulas, which were implanted under $2.5 \%$ isoflurane anesthesia (PE 50 for BP measurement in the left carotid artery, PE 10 for the infusion of drugs to the jugular vein), were exteriorized in the interscapular region. Blood pressure 
and heart rate (HR) were recorded using a pressure transducer and a multichannel recorder (ADInstruments, Bella Vista, Australia). We used a modified protocol of Minami et al. (1995) which was adapted in our laboratory (Kuneš et al. 2002, Vaněčková et al. 2012). Briefly, baseline MAP levels were recorded after a 30-min adaptation period in transparent measuring plastic cages. Then, we started with RAS blockade (captopril $10 \mathrm{mg} / \mathrm{kg}$ ) which was followed 15 min later by ganglionic blockade of SNS (pentolinium $5 \mathrm{mg} / \mathrm{kg}$ ). Finally, NO synthase inhibitor (30 mg/kg L-NAME) was injected and BP was monitored for further $20 \mathrm{~min}$. BP levels before and after particular blockades were determined and the respective BP changes were calculated. All drugs were dissolved in saline and administered as intravenous bolus injections in a volume of $1 \mathrm{ml} / \mathrm{kg}$ of body weight.

The results are expressed as the mean \pm SEM. The statistical differences were evaluated by one-way analysis of variance (ANOVA) (Instat, La Jolla, California, USA) followed by the Fisher LSD post-hoc test. $\mathrm{P}<0.05$ values were considered to be statistically significant.

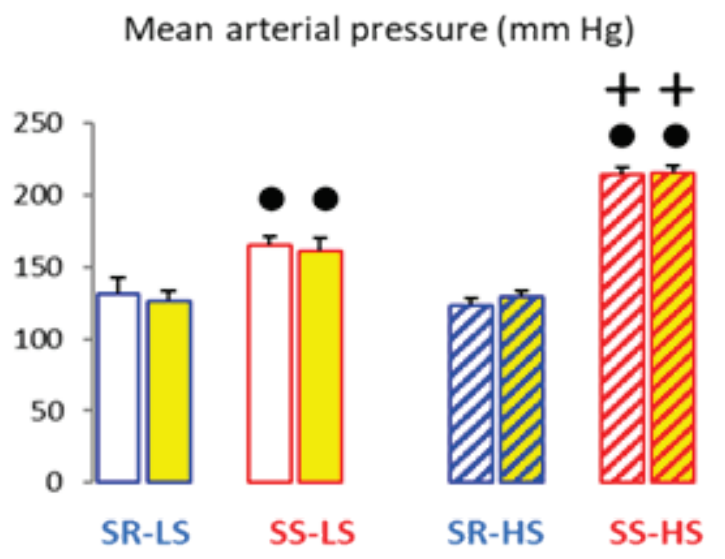

Pentolinium-induced MAP change $(\mathrm{mm} \mathrm{Hg})$
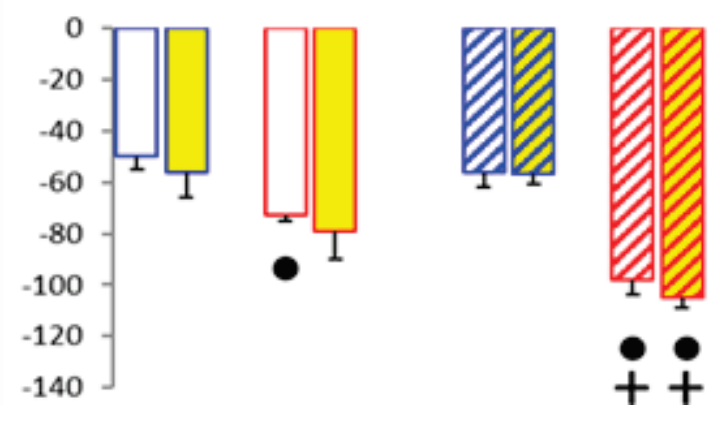

Fig. 1. Mean arterial pressure, heart rate, sympathetic BP component (pentolinium-induced BP change) and NO-dependent BP component (L-NAME-induced BP change) in conscious salt-resistant (SR/Jr, blue columns) and salt-sensitive (SS/Jr, red columns) Dahl rats that were fed a low-salt (LS) or high-salt (HS) diet and were drinking either water (columns with white background) or propranolol solution (columns with yellow background) for 6 weeks. Data are means \pm SEM, $n=9$. Significantly different $(p<0.05)$ : $\bullet S S / J r$ vs. $\mathrm{SR} / \mathrm{Jr}$ rats, ${ }^{+} \mathrm{HS}$ vs. LS animals, $*$ water drinking vs. propranolol-treated rats. 
Table 1. MAP changes elicited by acute captopril administration in conscious salt-resistant (SR/Jr) and salt-sensitive (SS/Jr) Dahl rats that were fed a low-salt (LS) or high-salt (HS) diet and were drinking either water or propranolol solution for 6 weeks.

\begin{tabular}{lllll}
\hline & SR-LS & SS-LS & SR-HS & SS-HS \\
\hline Water drinking & $-6.5 \pm 1.8$ & $-2.3 \pm 1.2$ & $-12.2 \pm 3.4$ & $-9.3 \pm 3.4$ \\
Propranolol-treated & $-5.6 \pm 1.1$ & $-3.9 \pm 1.7$ & $-6.3 \pm 2.2$ & $-4.3 \pm 1.8$ \\
\hline
\end{tabular}

Data are means \pm SEM, $n=9$.

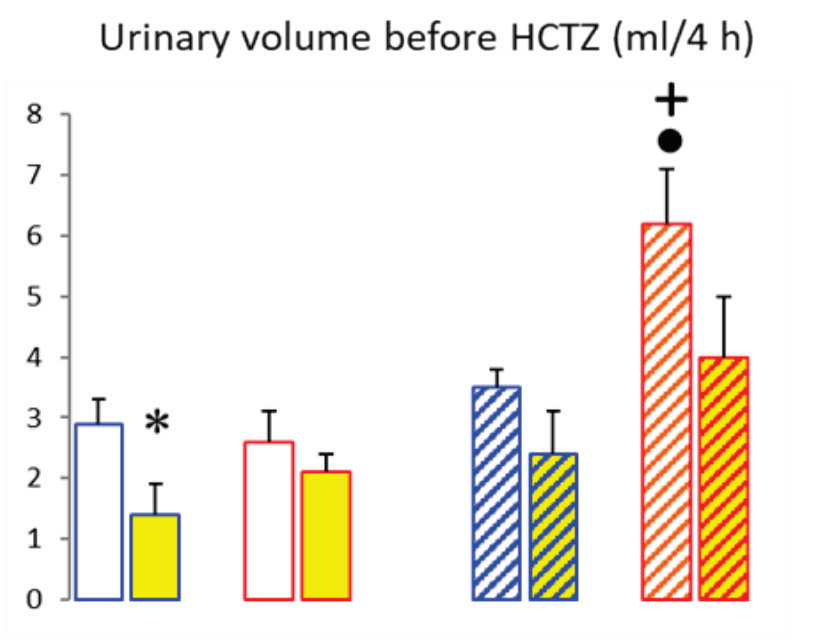

\section{Sodium excretion before HCTZ ( $\mu \mathrm{mol} / 4 \mathrm{~h})$}
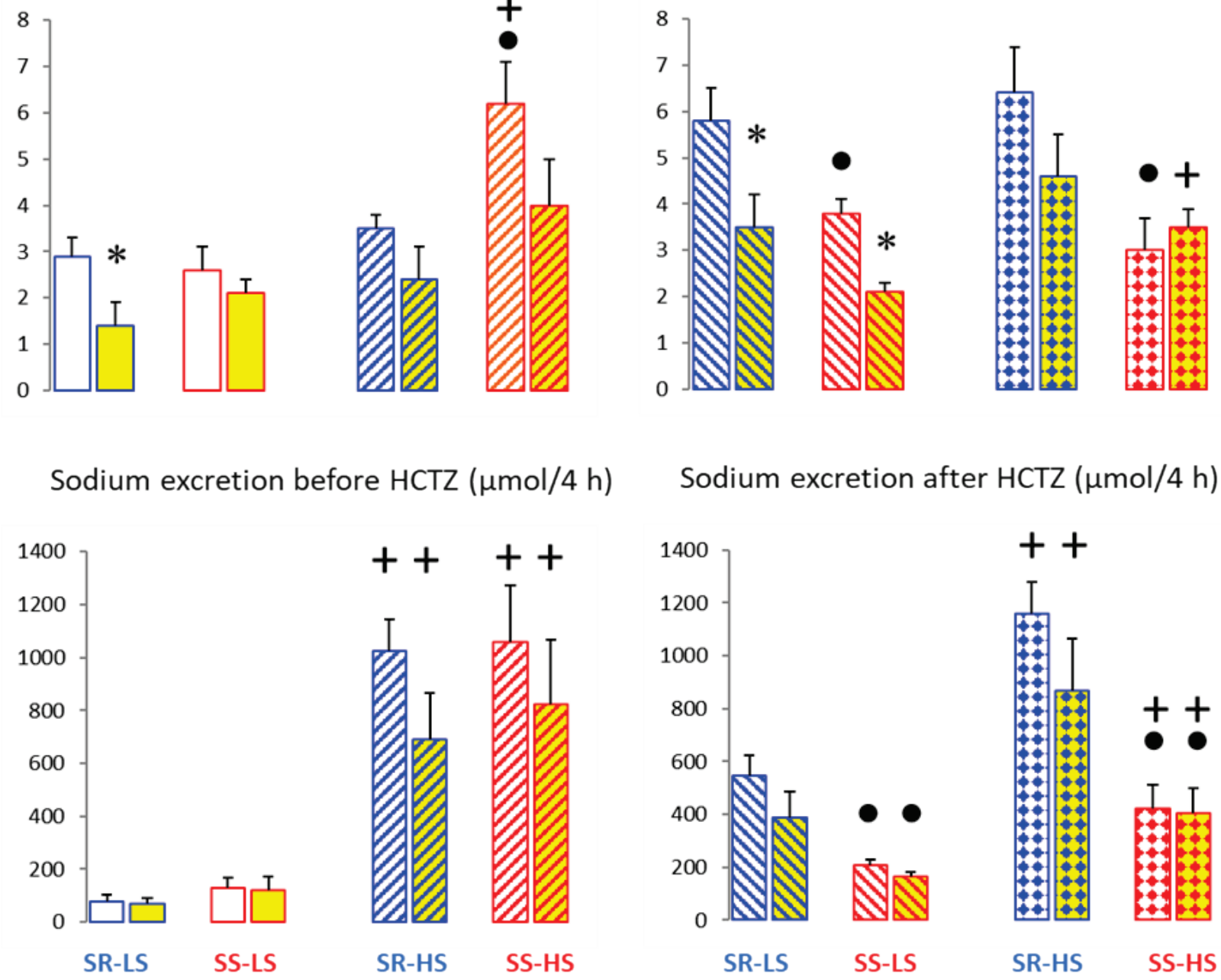

Fig. 2. The influence of chronic $\beta$-blockade with propranolol on urinary water and sodium excreted $4 \mathrm{~h}$ before and $4 \mathrm{~h}$ after hydrochlorothiazide injection (10 mg/kg, HCTZ, applied at 12 a.m.) by conscious salt-resistant (SR/Jr, blue columns) and salt-sensitive (SS/Jr, red columns) Dahl rats that were fed a low-salt (LS) or high-salt (HS) diet and were drinking either water (columns with white background) or propranolol solution (columns with yellow background) for 6 weeks. Data are means $\pm S E M, n=7$. Significantly different $(p<0.05):{ }^{+}$HS vs. LS animals, * water drinking vs. propranolol-treated rats.

Diuretic and natriuretic effects of acute HCTZ administration were strongly dependent on genotype of rats and their salt intake. In animals, which were not treated with propranolol, HCTZ injection increased urinary water excretion in $\mathrm{SR} / \mathrm{Jr}$ but not in $\mathrm{SS} / \mathrm{Jr}$ rats. Sodium excretion was enhanced by HCTZ only in SR/Jr rats fed a LS diet. Surprisingly, acute HCTZ administration reduced water and sodium excretion in salt hypertensive SS/Jr rats (Fig. 3, left panels). There were similar but less pronounced changes of diuresis and natriuresis in propranolol-treated animals (Fig. 3, right panels). 
Urinary volume ( $\mathrm{ml} / 4 \mathrm{~h})$
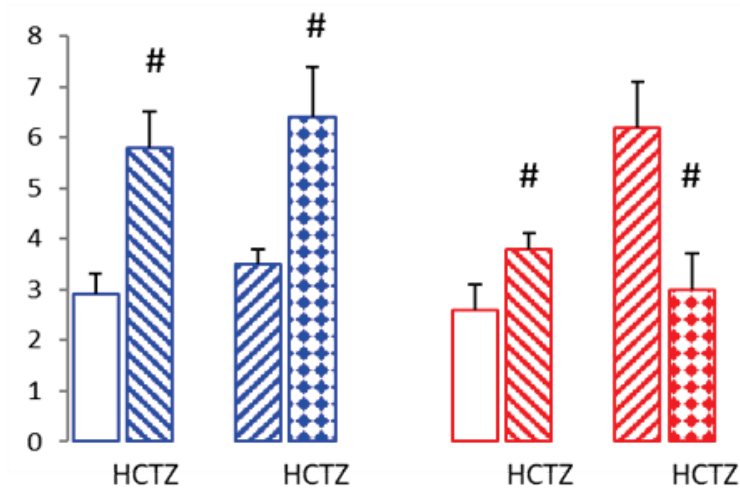

HCTZ HCTZ

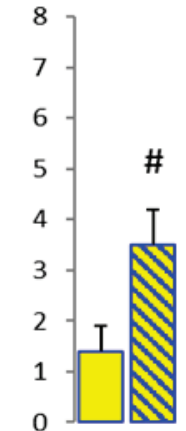

HCTZ

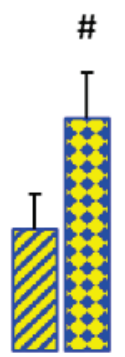

HCTZ

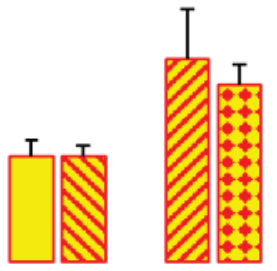

HCTZ

HCTZ

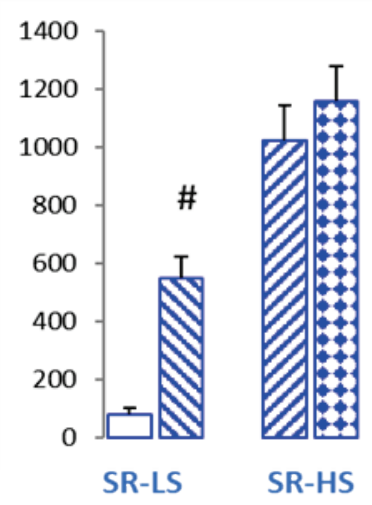

Sodium excretion ( $\mu \mathrm{mol} / 4 \mathrm{~h})$
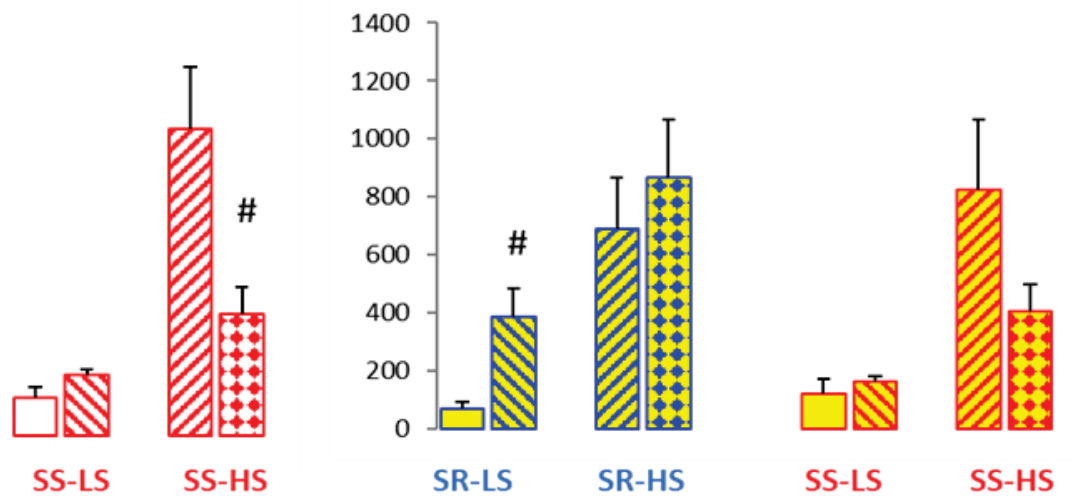

Fig. 3. The effect of hydrochlorothiazide ( $10 \mathrm{mg} / \mathrm{kg}, \mathrm{HCTZ}$ ) on water and sodium excretion in untreated (left panels) and propranololtreated (right panels) salt-resistant (SR/Jr, blue columns) and salt-sensitive (SS/Jr, red columns) Dahl rats fed a low-salt (LS) or highsalt (HS) diet. Data are means $\pm S E M, n=7$. Significantly different $(p<0.05):{ }^{*}$ HCTZ vs. saline injection.

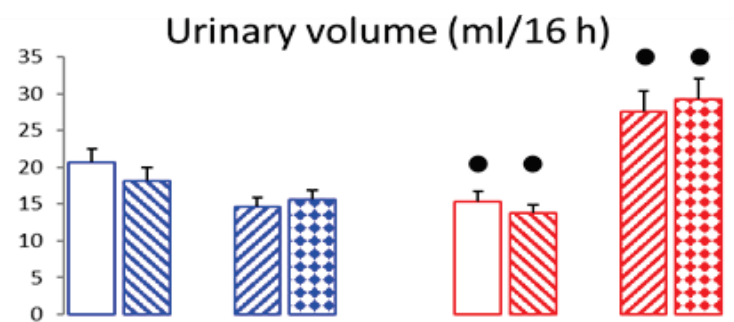

Sodium excretion ( $\mu \mathrm{mol} / 16 \mathrm{~h})$
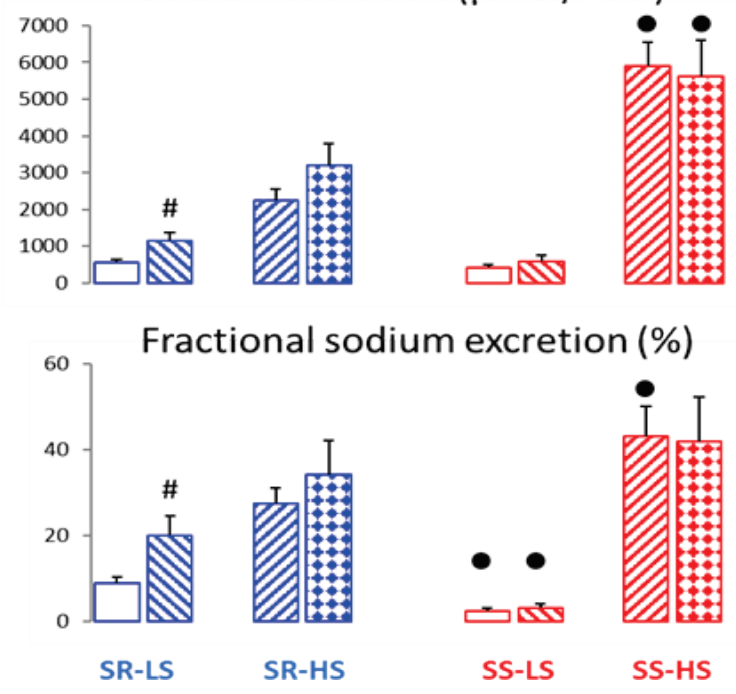

Fig. 4. The effect of hydrochlorothiazide $(10 \mathrm{mg} / \mathrm{kg}, \mathrm{HCTZ}$, applied at 4 p.m.) on overnight urinary water excretion, sodium excretion and fractional sodium excretion in untreated saltresistant (SR/Jr, blue columns) and salt-sensitive (SS/Jr, red columns) Dahl rats fed a low-salt (LS) or high-salt (HS) diet. Data are means \pm SEM, $n=8$. Significantly different $(p<0.05): \bullet S S / J r$ vs. SR/Jr rats, ${ }^{\#}$ HCTZ vs. saline injection.

To analyze the above genotype- and/or salt intake-dependent differences in HCTZ action on water and sodium excretion, that were obtained in shorter experiments carried out during the daytime, we have performed a further series of longer experiments with overnight collection of urine in Dahl rats untreated with propranolol. Figure 4 shows that under the conditions of low salt intake diuresis and natriuresis were moderately decreased in $\mathrm{SS} / \mathrm{Jr}$ rats compared to $\mathrm{SR} / \mathrm{Jr}$ ones, whereas both parameters were greatly enhanced in $\mathrm{SS} / \mathrm{Jr}$ rats fed a HS diet. The calculation of fractional sodium excretion revealed significantly lower values in $\mathrm{SS} / \mathrm{Jr}$ than $\mathrm{SR} / \mathrm{Jr}$ animals fed a LS diet, but significant HCTZ effect was seen only in SR/Jr animals. As expected, high salt intake greatly increased fractional sodium excretion in both rat 
strains (slightly more in SS/Jr animals) so that HCTZ can hardly elevate sodium excretion under these conditions (Fig. 4). Within this series of experiments, we have also studied the effect of loop diuretic furosemide and we have observed that $\mathrm{SS} / \mathrm{Jr}$ rats fed a LS diet responded to this diuretic better than SR/Jr animals (Fig. 5). There was no significant effect of furosemide in Dahl rats of either genotype when fed high-salt diet (data not shown).

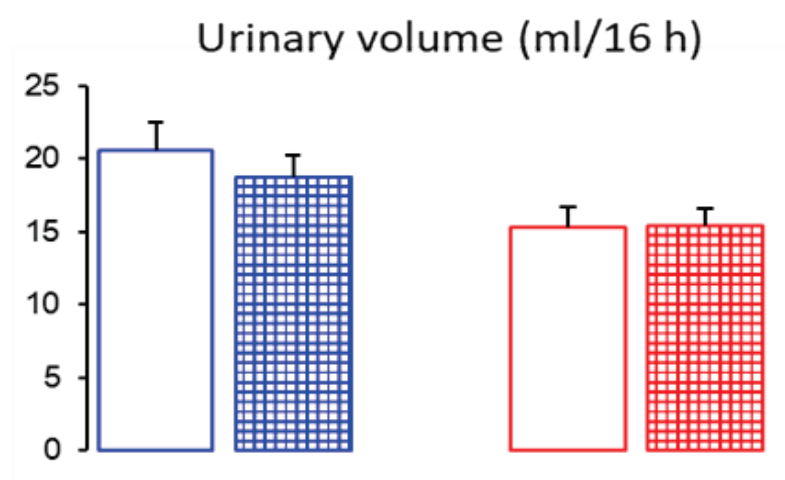

Sodium excretion ( $\mu \mathrm{mol} / 16 \mathrm{~h})$

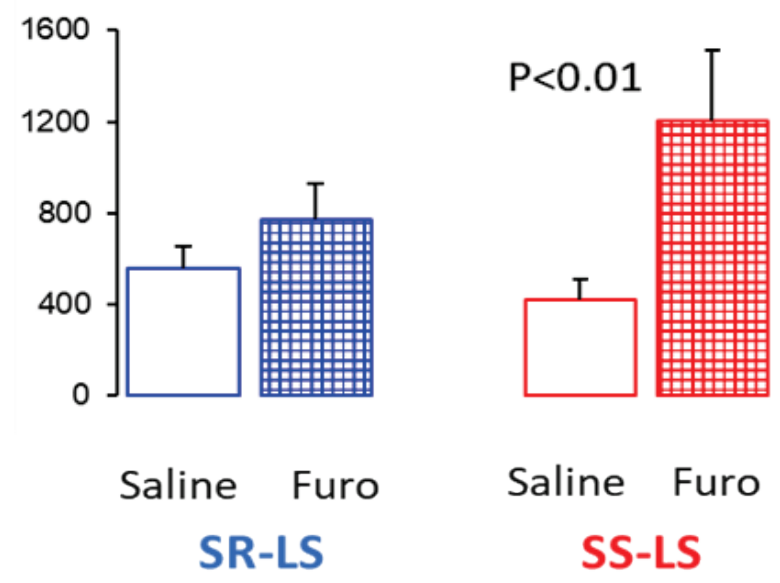

Fig. 5. The effect of furosemide (Furo, $10 \mathrm{mg} / \mathrm{kg}$, applied at 4 p.m.) on overnight urinary water and sodium excretion in untreated salt-resistant (SR/Jr, blue columns) and salt-sensitive (SS/Jr, red columns) Dahl rats fed a low-salt (LS). Data are means $\pm S E M, n=8$.

\section{Discussion}

Our study was designed to test the importance of renal $\beta$-adrenergic-WNK4-NCC pathway for the development of salt-induced hypertension in Dahl rats, which are characterized by enhanced sympathetic tone. We investigated the initial and the final steps of this interesting pathway proposed by $\mathrm{Mu}$ et al. (2011) in conscious animals. Therefore, we subjected our rats to chronic $\beta$-adrenergic blockade throughout the entire experiment and a non-selective $\beta$-blocker propranolol was used according to the study of $\mathrm{Mu}$ et al. (2011). Chronic propranolol treatment did not lower BP in any group studied, although the same treatment decreased BP of salt-loaded spontaneously hypertensive rats by $25 \mathrm{~mm} \mathrm{Hg}$ (Zicha, unpublished data). The only effect of chronic $\beta$-blockade was a significant reduction of heart rate in salt hypertensive Dahl rats treated with propranolol (Fig. 1). In fact, there are only few positive reports on BP-lowering effects of selective $\beta_{1}$-blockers such as atenolol, bisoprolol or nebivolol in salt hypertensive Dahl rats (Cosentino et al. 2002, Ye et al. 2013, Watanabe et al. 2015), but no information on BP effects of chronic $\beta_{2}$-adrenergic blockade is available in this model. Non-selective $\beta$-adrenergic blockade failed to attenuate salt hypertension in salt-sensitive Dahl rats (Puleo et al. 2019).

There is also scarce information on renal excretory effects of chronic $\beta$-blockade in Dahl rats. To our knowledge, Watanabe et al. (2015) did not observe any significant impact of chronic bisoprolol treatment on water and sodium excretion in salt hypertensive Dahl rats, which is in line with our present results (Fig. 2).

Finally, we were highly interested in the influence of chronic $\beta$-blockade with propranolol on diuretic and natriuretic response to acute administration of hydrochlorothiazide (HCTZ), which is an inhibitor of sodium-chloride cotransporter (NCC). Mu et al. (2011) reported that $\beta_{2^{-}}$but not $\beta_{1}$-adrenergic blockade attenuated natriuretic response to HCTZ injection in two models in which augmented response to HCTZ was observed - isoproterenol-treated Sprague Dawley rats fed a HS diet or DOCA-salt treated Sprague Dawley rats. Unfortunately, these authors did not provide any information on BP, sodium excretion or renal response to HCTZ in Dahl rats which they also included in their study (Mu et al. (2011).

In our study, we observed diuretic effects of HCTZ only in salt-resistant (SR/Jr) but not in saltsensitive (SS/Jr) Dahl rats and natriuretic effect of HCTZ was significant only in $\mathrm{SR} / \mathrm{Jr}$ animals fed a LS diet. Under the conditions of high salt intake, HCTZ did not increase sodium excretion in $\mathrm{SR} / \mathrm{Jr}$ rats and surprisingly lowered water and sodium excretion in SS/Jr animals. Chronic propranolol treatment did not influence natriuretic response to $\mathrm{HCTZ}$ in any experimental group including salt hypertensive SS/Jr rats (Fig. 3). Similar finding was also reported by Puleo et al. (2019) who did not observe significant reduction of NCC activity measured as peak natriuresis following i.v. HCTZ 
administration. Thus, our data suggest that $\beta_{2}$-adrenergic activation of NCC cannot be easily disclosed in salt hypertensive Dahl rats with sympathetic overactivity, although $\mathrm{Mu}$ et al. (2011) demonstrated that high salt intake increased WNK4 expression only in salt-resistant but not in salt-sensitive Dahl rats. On the basis of this observation they suggested a "relative suppression" of renal WNK4 in salt hypertensive rats and they expected (but not demonstrated) the activation of NCC in these animals.

Let us to discuss the above findings in the light of the available information on NCC in Dahl rats. Thiazide diuretics, which effectively lower BP in Dahl rats (Iwai et al. 1977, Yamada et al. 2011, Wei et al. 2017), target sodium-chloride cotransporter (NCC, earlier known as thiazide diuretic receptor). Surprisingly, the renal density of this cotransporter was not influenced by the excess dietary salt intake in either normotensive Sprague Dawley rats or salt-sensitive Dahl rats (Fanestil et al. 1997, 1999).

NCC has been studied in Dahl rats as a component of renal sodium transport and salt handling, but the interest was paid to the consequence of the knockout of either renin gene (Pavlov et al. 2016) or Kcnj16 gene for inward rectifying $\mathrm{K}^{+}$channel (Palygin et al. 2017) in salt-sensitive Dahl rats. This was a reason why a comparison of $\mathrm{SS} / \mathrm{Jr}$ with $\mathrm{SR} / \mathrm{Jr}$ rats was not included in these studies. Renin deficiency was associated with significantly lower protein expression of $\mathrm{Na}^{+} / \mathrm{H}^{+}$exchanger (NH3) and $\mathrm{Na}-\mathrm{Cl}$ cotransporter (NCC), whereas the expression of $\mathrm{Na}-\mathrm{K}-2 \mathrm{Cl}$ cotransporter ( $\mathrm{NKCC} 2)$ was unchanged (Pavlov et al. 2016). Since salt-sensitive Dahl rats are characterized by a lower RAS activity as compared to salt-resistant animals and this activity is further suppressed by high salt intake (Iwai et al. 1973), the higher activation of NCC in $\mathrm{SS} / \mathrm{Jr}$ than in SR/Jr is rather improbable. The second study revealed salt wasting in Kcnj16 knockout SS/Jr animals which was accompanied by the upregulation of both NCC and NKCC2 including their phosphorylated forms. Nevertheless, these knockout animals are characterized by decreased BP compared to intact $\mathrm{SS} / \mathrm{Jr}$ rats (Palygin et al. 2017). It should be mentioned that the earlier genetic studies in F2 generation of salt-resistant and salt-sensitive Dahl rats indicated that $\mathrm{Na}-\mathrm{K}-2 \mathrm{Cl}$ cotransport but not thiazide-sensitive sodium-chloride cotransport (NCC) is associated with BP of these saltloaded F2 hybrids (Herrera et al. 2001, Song et al. 2001).

The role of enhanced $\mathrm{Na}-\mathrm{K}-2 \mathrm{Cl}$ cotransport in
Dahl rats has already been suggested by old studies of erythrocyte ion transport (Knorr et al. 1985, Zicha and Duhm 1990). Later Garay and coworkers focused their attention on both NKCC1 (erythrocytes) and NKCC2 (kidney) in Dahl rats, demonstrating a circulating inhibitor of $\mathrm{Na}-\mathrm{K}-2 \mathrm{Cl}$ cotransporter in plasma of salt hypertensive Dahl rats (Alvarez-Guerra and Garay 1997, Garay et al. 1998, Alvarez-Guerra et al. 2002). In fact, our $\mathrm{SS} / \mathrm{Jr}$ rats fed a low-salt diet were insensitive to HCTZ (Fig. 4), but they displayed greater natriuretic response to $\mathrm{Na}-\mathrm{K}-2 \mathrm{Cl}$ cotransport inhibitor furosemide, whereas such response was almost absent in $\mathrm{SR} / \mathrm{Jr}$ rats (Fig. 5).

Actually there is a series of papers focusing the attention to NKCC2 transporter in thick ascending limb of Henle loop (TALH) in Dahl rats. Hong and Garvin (2012) found that the reduction of NKCC2 activity through angiotensin II (via $\mathrm{AT}_{2}$ receptors leading to NO release) is blunted in TALH of $\mathrm{SS} / \mathrm{Jr}$ rats. Haque et al. (2011) reported that high salt intake moderately decreased the activity of surface $\mathrm{NKCC} 2$ and sodium transport in TALH of SR/Jr rats, whereas these two parameters were substantially increased in TALH of $\mathrm{SS} / \mathrm{Jr}$ rats with high salt intake. The further study of this group (Ares et al. 2012) revealed hyperphosphorylation of NKCC2 and its enhanced trafficking into the apical membrane in TALH of salt-sensitive Dahl rats, leading to increased $\mathrm{NKCC} 2$ activity and abnormal sodium reabsorption compared to salt-resistant animals. Recently, Haque and Ortiz (2019) demonstrated in TALH of Sprague Dawley rats that the expression of surface NKCC 2 is increased by superoxide anions and blunted by endogenous NO. Superoxide-stimulated apical trafficking of NKCC2 may be involved in the enhanced surface NKCC2 expression observed in salt-sensitive Dahl rats. This also seems to be in accordance with our earlier findings on the interaction of superoxide with $\mathrm{NO}$ in salt hypertensive Dahl rats (Zicha et al. 2001).

Nevertheless, Fujita and coworkers also pointed out that renal WNK4 deficiency due its suppressed expression might activate epithelial sodium channels (ENaC) in the distal tubule (Mu et al. 2011, Nishimoto and Fujita 2015). The importance of $\mathrm{ENaC}$ in saltinduced hypertension was also considered by several other labs (Aoi et al. 2004, Kakizoe et al. 2009, Amin et al. 2011, Pavlov and Staruschenko 2017) and this mechanism may need further investigation in the future.

We can conclude that our present data do not support the essential importance of renal $\beta$-adrenergic- 
WNK4-NCC pathway in the maintenance of high blood pressure in salt hypertensive Dahl rats. It seems that $\mathrm{ENaC}$ channels and/or NKCC2 cotransporter in the kidney of saltsensitive Dahl rats might play a more important role in the pathogenesis of salt hypertension than NCC cotransporter.

It would be desirable to study the above mechanisms also in spontaneously hypertensive rats (SHR) in which various renal abnormalities (Persson and Boberg 1988, Cowley et al. 1992, José et al. 1996, Moreno et al. 2001, Ahmeda et al. 2018) as well as sympathetic hyperactivity (Zicha et al. 2014, Török et al. 2016, Vavř́nová et al. 2016) including altered $\beta$-adrenergic vasodilatation (Pintérová et al. 2014) were reported. The comparison of both models of experimental hypertension could be highly interesting.

\section{Note added in proof}

Recent research on the sympathetic regulation of NCC activity in rats with various forms of salt-sensitive hypertension indicated that norepinephrine modulates NCC activity through its action on $\alpha_{1}$ - rather than $\beta$-adrenergic receptors (Frame et al. 2019, Puleo et al. 2019, R.D. Wainford - personal communication).

\section{Conflict of Interest}

There is no conflict of interest.

\section{Acknowledgements}

Technical assistance of Zdeňka Kopecká and Alena Charvátová is highly appreciated. The study was supported by research grant of the Ministry of Health of the Czech Republic (15-25396A) and by an institutional support (RV0:67985823).

\section{References}

AHMEDA AF, RAE MG, ANWEIGI LM, AL OTAIBI MF, AL-MASRI AA, JOHNS EJ: The effect of superoxide dismutase enzyme inhibition on renal microcirculation of spontaneously hypertensive-stroke prone and Wistar rats. Physiol Res 67: 535-541, 2018.

ALVAREZ-GUERRA M, GARAY RP: Renal Na-K-Cl cotransporter NKCC2 in Dahl salt-sensitive rats. J Hypertens 20: 721-727, 2002.

ALVAREZ-GUERRA M, VARGAS F, ALDA JO, GARAY RP: Endogenous inhibitor of Na-K-Cl cotransport system in inbred Dahl rats. Am J Physiol 272: F356-F363, 1997.

AMIN MS, REZA E, EL-SHAHAT E, WANG HW, TESSON F, LEENEN FH: Enhanced expression of epithelial sodium channels in the renal medulla of Dahl S rats. Can J Physiol Pharmacol 89: 159-168. 2011.

AOI W, NIISATO N, MIYAZAKI H, MARUNAKA Y: Flavonoid-induced reduction of ENaC expression in the kidney of Dahl salt-sensitive hypertensive rat. Biochem Biophys Res Commun 315: 892-896, 2004.

ARES GR, HAQUE MZ, DELPIRE E, ORTIZ PA: Hyperphosphorylation of Na-K-2Cl cotransporter in thick ascending limbs of Dahl salt-sensitive rats. Hypertension 60: 1464-1470, 2012.

COSENTINO F, BONETTI S, REHORIK R, ETO M, WERNER-FELMAYER G, VOLPE M, LÜSCHER TF: Nitricoxide-mediated relaxations in salt-induced hypertension: effect of chronic betal -selective receptor blockade. J Hypertens 20: 421-428, 2002.

COWLEY AW, ROMAN RJ, FENOY FJ, MATTSON DL: Effect of renal medullary circulation on arterial pressure. J Hypertens 10 (Suppl 7): S187-S193, 1992.

DAHL LK, HEINE M, TASSINARI L: Effects of chronic excess salt ingestion. Evidence that genetic factors play an important role in susceptibility to experimental hypertension. J Exp Med 115: 1173-1190, 1962.

DOBEŠOVÁ Z, KUNEŠ J, ZICHA J: The altered balance between sympathetic nervous system and nitric oxide in salt hypertensive Dahl rats: ontogenetic and F2 hybrid studies. J Hypertens 20: 945-955, 2002.

FANESTIL DD, VAUGHN DA, BLAKELY P: Dietary $\mathrm{NaCl}$ and $\mathrm{KCl}$ do not regulate renal density of the thiazide diuretic receptor. Am J Physiol 273: R1241-R1245, 1997.

FANESTIL DD, VAUGHN DA, HYDE RH, BLAKELY P: Genetic control of renal thiazide receptor response to dietary $\mathrm{NaCl}$ and hypertension. Am J Physiol 276: R901-R904, 1999.

FRAME AA, PULEO F, KIM K, WALSH KR, FAUDOA E, HOOVER RS, WAINFORD RD: Sympathetic regulation of the NCC in norepinephrine-evoked salt-sensitive hypertension in Sprague-Dawley rats. Am J Physiol Renal Physiol 2019. doi: 10.1152/ajprenal.00264.2019. 
FUJITA T: Mechanism of salt-sensitive hypertension: focus on adrenal and sympathetic nervous systems. $J$ Am Soc Nephrol 25: 1148-1155, 2014.

FUJITA T, HENRY WL, BARTTER FC, LAKE CR, DELEA CS: Factors influencing blood pressure in salt-sensitive patients with hypertension. Am J Med 69: 334-344, 1980.

GARAY RP, ALVAREZ-GUERRA M, ALDA JO, NAZARET C, SOLER A, VARGAS F: Regulation of renal $\mathrm{Na}-\mathrm{K}-\mathrm{Cl}$ cotransporter NKCC2 by humoral natriuretic factors: relevance in hypertension. Clin Exp Hypertens 20: 675-682, 1998.

HAQUE MZ, ORTIZ PA: Superoxide increases surface NKCC2 in the rat thick ascending limbs via PKC. Am J Physiol Renal Physiol 317: F99-F106, 2019.

HAQUE MZ, ARES GR, CACERES PS, ORTIZ PA: High salt differentially regulates surface NKCC2 expression in thick ascending limbs of Dahl salt-sensitive and salt-resistant rats. Am J Physiol Renal Physiol 300: F1096-F1104, 2011.

HERRERA VL, LOPEZ LV, RUIZ-OPAZO N: Alpha1 Na,K-ATPase and Na,K,2Cl-cotransporte/D3mit3 loci interact to increase susceptibility to salt-sensitive hypertension in Dahl S(HSD) rats. Mol Med 7: 125-134, 2001.

HONG NJ, GARVIN JL: Angiotensin II type 2 receptor-mediated inhibition of $\mathrm{NaCl}$ absorption is blunted in thick ascending limbs from Dahl salt-sensitive rats. Hypertension 60: 765-769, 2012.

HUANG BS, LEENEN FH: Both brain angiotensin II and "ouabain" contribute to sympathoexcitation and hypertension in Dahl S rats on high salt intake. Hypertension 32: 1028-1033, 1998.

IWAI J, DAHL LK, KNUDSEN KD: Genetic influence on the renin-angiotensin system: low renin activities in hypertension-prone rats. Circ Res 32: 678-684, 1973.

IWAI J, OHANIAN EV, DAHL LK: Influence of thiazide on salt hypertension. Circ Res 40 (Suppl I): I131-I134, 1977.

JOSE PA, EISNER GM, DRAGO J, CAREY RM, FELDER RA: Dopamine receptor signaling defects in spontaneous hypertension. Am J Hypertens 9: 400-405, 1996.

KAKIZOE Y, KITAMURA K, KO T, WAKIDA N, MAEKAWA A, MIYOSHI T, SHIRAISHI N, ADACHI M, ZHANG Z, MASILAMANI S, TOMITA K: Aberrant ENaC activation in Dahl salt-sensitive rats. J Hypertens 27: 1679-1689, 2009.

KITTIKULSUTH W, HYNDMAN KA, POLLOCK JS, POLLOCK DM: Natriuretic response to renal medullary endothelin B receptor activation is impaired in Dahl-salt sensitive rats on a high-fat diet. Physiol Res 67 (Suppl 1): S149-S154, 2018.

KNORR A, DE MENDONÇA M, GARTHOFF B, MORICH F, KAZDA S: Chronic treatment with nifedipine prevents development of hypertension and abnormal red cell $\mathrm{Na}^{+}$transport in Dahl-S-rats. Arch Int Pharmacodyn Ther 275: 248-258, 1985.

KUNEŠ J, DOBEŠOVÁ Z, ZICHA J: Altered balance of main vasopressor and vasodepressor systems in rats with genetic hypertension and hypertriglyceridaemia. Clin Sci (Lond) 102: 269-277, 2002.

MARK AL: Sympathetic neural contribution to salt-induced hypertension in Dahl rats. Hypertension 17 (Suppl I): I86-I90, 1991.

MINAMI N, IMAI Y, HASHIMOTO J, ABE K: Contribution of vascular nitric oxide to basal blood pressure in conscious spontaneously hypertensive rats and normotensive Wistar Kyoto rats. Clin Sci (Lond) 89: 177-182, 1995.

MORENO C, MAIER KG, HOAGLAND KM, YU M, ROMAN RJ: Abnormal pressure-natriuresis in hypertension: role of cytochrome P450 metabolites of arachidonic acid. Am J Hypertens 14: 90S-97S, 2001.

MU S, SHIMOSAWA T, OGURA S, WANG H, UETAKE Y, KAWAKAMI-MORI F, MARUMO T, YATOMI Y, GELLER DS, TANAKA H, FUJITA T: Epigenetic modulation of the renal $\beta$-adrenergic-WNK4 pathway in salt-sensitive hypertension. Nat Med 17: 573-580, 2011.

NISHIMOTO M, FUJITA T: Renal mechanisms of salt-sensitive hypertension: contribution of two steroid receptorassociated pathways. Am J Physiol Renal Physiol 308: F377-F387, 2015.

PALYGIN O, LEVCHENKO V, ILATOVSKAYA DV, PAVLOV TS, POCHYNYUK OM, JACOB HJ, GEURTS AM, HODGES MR, STARUSCHENKO A: Essential role of Kir5.1 channels in renal salt handling and blood pressure control. JCI Insight 2. pii: 92331, 2017. doi: 10.1172/jci.insight.92331.

PAVLOV TS, STARUSCHENKO A: Involvement of ENaC in the development of salt-sensitive hypertension. $A m \mathrm{~J}$ Physiol Renal Physiol 313: F135-F140, 2017. 
PAVLOV TS, LEVCHENKO V, ILATOVSKAYA DV, MORENO C, STARUSCHENKO A: Renal sodium transport in renin-deficient Dahl salt-sensitive rats. J Renin Angiotensin Aldosterone Syst 17. pii: 1470320316653858, 2016.

PERSSON AE, BOBERG U: Renal abnormalities in experimental models of hypertension: the SHR versus the Milan HR. J Cardiovasc Pharmacol 12 (Suppl 3): S27-S35, 1988.

PINTÉROVÁ M, BEHULIAK M, KUNEŠ J, ZICHA J: Involvement of $\mathrm{BK}_{\mathrm{Ca}}$ and $\mathrm{K}_{\mathrm{V}}$ potassium channels in cAMPinduced vasodilatation: their insufficient function in genetic hypertension. Physiol Res 63: 275-285, 2014.

PULEO F, FRAME AA, MOREIRA JD, FAUDOA E, WAINFORD RD: $\alpha 1$-adrenoceptor antagonism attenuates the development and progression of Dahl salt sensitive rat hypertension by modulating NCC activity. FASEB J 33 (1, Suppl): abstract 569.17, 2019.

SHARMA JN, FERNANDEZ PG, KIM BK, TRIGGLE CR: Systolic blood pressure responses to enalapril maleate (MK 421, an angiotensin converting enzyme inhibitor) and hydrochlorothiazide in conscious Dahl saltsensitive and salt-resistant rats. Can J Physiol Pharmacol 62: 846-869, 1984.

SONG Y, HERRERA VL, FILIGHEDDU F, TROFFA C, LOPEZ LV, GLORIOSO N, RUIZ-OPAZO N: Non-association of the thiazide-sensitive $\mathrm{Na}, \mathrm{Cl}$-cotransporter gene with polygenic hypertension in both rats and humans. J Hypertens 19: 1547-1551, 2001.

TOBIAN L, LANGE J, IWAI J, HILLER K, JOHNSON MA, GOOSSENS P: Prevention with thiazide of NaClinduced hypertension in Dahl "S" rats. Evidence for a Na-retaining humoral agent in "S" rats. Hypertension 1: 316-323, 1979.

TÖRÖK J, ZEMANČÍKOVÁ A, KOCIANOVÁ Z: Interaction of perivascular adipose tissue and sympathetic nerves in arteries from normotensive and hypertensive rats. Physiol Res 65 (Suppl 3): S391-S399, 2016.

VAVŘÍNOVÁ A, BEHULIAK M, ZICHA J: The importance of the selection of appropriate reference genes for gene expression profiling in adrenal medulla or sympathetic ganglia of spontaneously hypertensive rat. Physiol Res 65: 401-11, 2016.

VOKURKOVÁ M, RAUCHOVÁ H, ŘEZÁČOVÁ L, VANĚČKOVÁ I, ZICHA J: ROS production is increased in the kidney but not in the brain of Dahl rats with salt hypertension elicited in adulthood. Physiol Res 64: 303-312, 2015.

WATANABE H, IWANAGA Y, MIYAJI Y, YAMAMOTO H, MIYAZAKI S: Renal denervation mitigates cardiac remodeling and renal damage in Dahl rats: a comparison with $\beta$-receptor blockade. Hypertens Res 39: 217-226, 2016.

WEI SY, WANG YX, ZHANG QF, ZHAO SL, DIAO TT, LI JS, QI WR, HE YX, GUO XY, ZHANG MZ, CHEN JY, WANG XT, WEI QJ, WANG Y, LI B: Multiple mechanisms are involved in salt-sensitive hypertensioninduced renal injury and interstitial fibrosis. Sci Rep 7: 45952, 2017.

YAMADA Y, TSUBOI K, HATTORI T, MURASE T, OHTAKE M, FURUKAWA M, UEYAMA J, NISHIYAMA A, MUROHARA T, NAGATA K: Mechanism underlying the efficacy of combination therapy with losartan and hydrochlorothiazide in rats with salt-sensitive hypertension. Hypertens Res 34: 809-816, 2011.

YE H, LING S, CASTILlO AC, THOMAS B, LONG B, QIAN J, PEREZ-POLO JR, YE Y, CHEN X, BIRNBAUM $Y$ : Nebivolol induces distinct changes in profibrosis microRNA expression compared with atenolol, in saltsensitive hypertensive rats. Hypertension 61: 1008-1013, 2013.

ZICHA J, DUHM J: Kinetics of $\mathrm{Na}^{+}$and $\mathrm{K}^{+}$transport in red blood cells of Dahl rats. Effects of age and salt. Hypertension 15: 612-627, 1990.

ZICHA J, DOBEŠOVÁ Z, KUNEŠ J: Relative deficiency of nitric oxide-dependent vasodilation in salt-hypertensive Dahl rats: the possible role of superoxide anions. J Hypertens 19: 247-254, 2001.

ZICHA J, DOBEŠOVÁ Z, VOKURKOVÁ M, RAUCHOVÁ H, HOJNÁ S, KADLECOVÁ M, BEHULIAK M, VANĚČKOVÁ I, KUNEŠ J: Age-dependent salt hypertension in Dahl rats: fifty years of research. Physiol Res 61 (Suppl 1): S35-S87, 2012.

ZICHA J, DOBEŠOVÁ Z, BEHULIAK M, PINTÉROVÁ M, KUNEŠ J, VANĚČKOVÁ I: Nifedipine-sensitive blood pressure component in hypertensive models characterized by high activity of either sympathetic nervous system or renin-angiotensin system. Physiol Res 63: 13-26, 2014. 